\title{
$\stackrel{\odot}{\Perp}$ \\ O INTRYGUJĄCYM, CHOĆ NIECO ZAPOMNIANYM STULATKU. WPROWADZENIE REDAKTORA TOMU
}

ABSTRACT. Marek Nowak, O intrygującym, choć nieco zapomnianym stulatku. Wprowadzenie redaktora tomu [An interesting, though somewhat forgotten, one century-old. Introduction by the editor of the volume] edited by M. Nowak ", Człowiek i Społeczeństwo" vol. XLVII: "Chłop polski w Europie i Ameryce" po stu latach [Polish peasant in Europe and America after one hundred years], Poznań 2019, pp. 7-17, Adam Mickiewicz University. Faculty of Social Sciences Press. ISSN 0239-3271.

Marek Nowak, Uniwersytet im. Adama Mickiewicza w Poznaniu, Wydział Nauk Społecznych, Instytut Socjologii, ul. Szamarzewskiego 89, 60-568 Poznań, e-mail: marek.nowak@amu.edu.pl

Tom ten stanowi jeden ze śladów, jakie pozostawiło po sobie stulecie wydania Chłopa polskiego w Europie i Ameryce Williama Thomasa i Floriana Znanieckiego. Wydarzenie to, jakkolwiek samo w sobie znaczące (choćby przez dystans czasu od wydania pracy), uruchomiło wątki tożsamościowej dyskusji socjologów, których przedmiotem był jeden z fundamentów socjologii jakościowej; ponadto stało się jasne, że problematyka dzieła (zagadnienia stosunku migrantów do kultury obszaru pochodzenia i kultury obszaru - celu emigracji) stała się aktualna na poziomie dyskursu publicznego. Można było więc oczekiwać niezwykłej dynamiki dyskusji i czegoś na kształt nawału wydarzeń odwołujących się bądź to do tradycji socjologii humanistycznej i opartego na niej paradygmatu interpretatywnego zawartych w Chłopie polskim..., bądź to do zagadnień migracyjnych i zasadniczych dla pracy kwestii dezintegracji i reintegracji społecznej. 
W istocie jednak nic takiego się nie stało. Uwaga ta dotyczy szczególnie środowiska poznańskiego, gdzie z jednej strony Znaniecki i jego związki z socjologią amerykańską były przedmiotem ożywionej refleksji i studiów ojców odrodzonej socjologii w Poznaniu, profesorów: Zygmunta Dulczewskiego (autora pracy Florian Znaniecki: życie i dzieło, 1984), Andrzeja Kwileckiego (redaktora pracy zbiorowej Florian Znaniecki i jego rola w socjologii, 1975) i Janusza Ziółkowskiego (kontynuator studiów Znanieckiego z zakresu socjologii miasta, współautora pracy Czym jest dla ciebie miasto Poznań?, 1984), z drugiej zaś późniejszy rozwój socjologii uniwersyteckiej wskazywał raczej na poszukiwania tożsamości ośrodka poza dziedzictwem z przełomu wieków. W pewnym sensie zatem niezwykle trudno jest dosięgnąć poziomu wyznaczonego pracami wymienionych autorów, nawet jeżeli stanowią one zbiorowe dziedzictwo, do którego socjologowie poznańscy chętnie się dopisują.

Analiza wydarzeń rocznicowych pozwala na stwierdzenie (a jest to subiektywny wniosek redaktora tomu), że najgłębsze ślady pozostawiła nie teoria, w tym np. teoria wartości Znanieckiego (bądź też konstrukcja postawy Williama I. Thomasa), ale zawarte w pracy założenia metodologiczne. Poświęcano temu zagadnieniu stosunkowo najwięcej miejsca, co jest, z jednej strony, świadectwem sukcesu perspektywy metodologicznej, lub bardziej precyzyjnie: perspektywy paradygmatycznej badań biograficznych w instrumentarium współczesnej, w istotnej mierze jakościowej socjologii. Z drugiej strony świadczy o pewnej słabości kontynuacji refleksji teoretycznej, prowadząc do wniosków na temat słabszej kondycji teorii zapoczątkowanej przez Znanieckiego i rozwijanej w Polsce z różną dynamiką w okresie, gdy dyscyplina, co najmniej dydaktycznie, wróciła na uniwersytety (a dla poznańskiego ośrodka socjologicznego był to koniec lat sześćdziesiątych XX w.).

Co intrygujące, bardziej w odniesieniu do metody niż do teorii, centrum dyskusji na temat stulecia umiejscowione było w Polsce w ośrodkach łódzkim, poznańskim i wrocławskim. W Łodzi w 2018 r. zrealizowany został, rozłożony na cały rok, cykl niezwykle ciekawych seminariów skupiających badaczy z całego kraju ${ }^{1}$, we wrześniu miała miejsce duża konferencja sekcji

${ }^{1}$ Tematyka kolejnych seminariów dotyczyła następujących kwestii: metodologia, procesy społeczne w relacji do jednostki, migracja oraz dezorganizacja i kryzys. Szczegółowy opis seminariów można znaleźć na stronie Wydziału Ekonomiczno-Społecznego Uniwersytetu Łódzkiego: https://www.eksoc.uni.lodz.pl/stulecie-wydania-ksiazki-chloppolski-w-europie-i-ameryce-williama-thomasa-i-floriana-znanieckiego-1918-1920/, dostęp: listopad 2019. 
Europejskiego Towarzystwa Socjologicznego poświęcona empirycznej refleksji nad społeczną dezorganizacją i obcością w społeczeństwach europejskich, eksplorująca jednocześnie perspektywy analizy biograficznej². Podobne, jeśli chodzi o empiryczny profil zainteresowań, były założenia konferencji, która w maju tegoż roku odbyła się we Wrocławiu33. W Poznaniu, również w maju, miała miejsce duża rocznicowa konferencja z udziałem socjologów amerykańskich.

\section{Obchody poznańskie}

24 i 25 maja 2018 r. w Collegium Minus UAM odbyła się chronologicznie druga (po wrocławskiej) konferencja rocznicowa zatytułowana „A Centennial of the Polish Peasant in Europe and America: Inspiration of Thomas and Znaniecki's Work for Sociological Scholarship on the Contemporary Globalization Processes”. Jej założenia, przynajmniej w intencjach organizatorów, miały eksplorować obecność opus magnum Thomasa i Znanieckiego w odniesieniu do bezpośrednich nawiązań i historycznych analiz, podejmując zamysł - inspirowany studiami Znanieckiego i Thomasa - podtrzymania związku pomiędzy środowiskami socjologicznymi po obu stronach Atlantyku. W Poznaniu zgromadzono znaczące grono socjologów amerykańskich oraz przedstawicieli socjologii europejskiej. Gośćmi konferencji byli m.in.: prof. Mary Waters (Harvard University, Cambridge, MA), prof. Michael Burawoy (University of California, Berkeley), a także prof. Eli Zaretsky (The New School for Social Research, Nowy Jork). Konferencję współorganizowały instytucje podtrzymujące tradycję związaną z pamięcią o Florianie Znanieckim: Instytut Socjologii UAM, Fundacja Naukowa im. Floriana Znanieckiego, Towarzystwo im. Floriana Znanieckiego oraz Haverford Institute of Public Sociology. W zaproszeniu do udziału w konferencji pojawił się szeroki zakres tematyczny niepozbawiony radykalnej nuty, który miał ogniskować się wokół tradycji wyznaczonej współpracą

${ }^{2}$ Co warto podkreślić, spotkania badaczy miały formę warsztatów, włączając w to bliskie Thomasowi i Znanieckiemu analizy tekstów autobiograficznych.

${ }^{3}$ Konferencja zatytułowana „W przestrzeni biografii - identyfikacja doświadczeń, procesów i zmian” odbyła się w dniach 9-11 maja 2018 r. na Wydziale Nauk Pedagogicznych Dolnośląskiej Szkoły Wyższej we Wrocławiu. Szczegółowe informacje dotyczące wydarzenia można odnaleźć w publikacji Marty Medyńskiej zatytułowanej Międzynarodowa Konferencja Naukowa z okazji 100-lecia wydania dzieła „Chłop polski w Europie i Ameryce" Williama I. Thomasa i Floriana Znanieckiego, Wrocław, 9-11 maja 2018 roku, opublikowanej w czasopiśmie „Teraźniejszość - Człowiek - Edukacja” 3/2018. 
polskiego filozofa (późniejszego socjologa) i amerykańskiego socjologa empiryka. Jak pisali organizatorzy konferencji: „Książka zainspirowała analizy społeczeństw, ściśle związane ze sprawiedliwością społeczną, świadomą polityką społeczną...”, monografia „zastąpiła biologiczne koncepcje ewolucji specyficznym socjologicznym i kulturowym mechanizmem zmian. Wniosła cenny wkład w metodologiczny rozwój nauk społecznych w Stanach Zjednoczonych, rozpoczynając przejście od studiów spekulatywnych do badań opartych na danych empirycznych. Chłop polski... jest uważany za najbardziej reprezentatywną pracę Szkoły Chicagowskiej w socjologii, która rozwinęła model społecznie zakorzenionego, refleksyjnego i intencjonalnego człowieka; podkreśliła wzajemne oddziaływanie między czynnikami subiektywnymi i obiektywnymi, rozwinęła koncepcję ludzkiej woli i symbolicznego znaczenia jako konstytutywnych dla działań, praktyk i instytucji w społeczeństwie"4.

Konferencja stawiała sobie wiele celów. Najważniejsze dwa to: (1) „rewitalizacja” problematyki poruszanej przez obydwu autorów pracy Chłop polski..., a szczególnie przez Floriana Znanieckiego, oraz (2) pokuszenie się o zbadanie potencjału naukowego zawartego w formule współpracy polsko-amerykańskiej, na gruncie składnika wspólnej tradycji badań społecznych. Pierwszy z celów okazał się trudniejszy w realizacji niż drugi. Okazało się, że tradycja badań kulturalistycznych Znanieckiego połączona ze świadomością jej źródeł jest stosunkowo słabo kultywowana na uniwersytetach amerykańskich. Z drugiej jednak strony istnieje otwartość na stawianie nowych problemów w starym świetle, chodzi tu szczególnie o tradycję szkoły chicagowskiej. Co ciekawe, spore zainteresowanie problematyką wyrazili przedstawiciele środowiska badawczego z Nowego Jorku (The New School for Social Research); podobnie zresztą pojawiło się kilka interesujących prezentacji dotyczących polskich migrantów/Polonii w Nowym Jorkus.

Domykając wątek organizacyjny, wypada podziękować wszystkim podmiotom (instytucjom) za zaangażowanie się w obchody stulecia Chłopa

${ }^{4}$ Fragment Call for paper opublikowanego na stronie Instytutu Socjologii UAM, http://socjologia.amu.edu.pl/new/, dostęp: październik 2019.

${ }^{5}$ Konferencja, w odróżnieniu od wcześniej wzmiankowanej dyskusji skoncentrowanej na metodzie, w większym stopniu eksplorowała zagadnienia teoretyczne i perspektywy przedmiotu badań, jakimi w tym przypadku były kwestie migracji, pozycji migrantów i integracji społecznej. Podobnie było podczas konferencji, jaka odbyła się na Wydziale Nauk Edukacyjnych UAM w Poznaniu w drugiej połowie roku, dedykowanej bezpośrednio drugiemu ze współautorów pracy: Florianowi Znanieckiemu. 
polskiego... w Poznaniu. Należy wskazać co najmniej dwie instytucje: Biuro Prezydenta Miasta Poznania Jacka Jaśkowiaka, dzięki dotacji którego możliwe było zaproszenie Profesora Michaela Burawoya, oraz władze rektorskie Uniwersytetu im. Adama Mickiewicza w Poznaniu za wzięcie na siebie lwiej części kosztów organizacji konferencji, która odbyła się również w ramach stulecia obchodów Uniwersytetu Poznańskiego. Wypada też podziękować konkretnym osobom: Sławie Zbierskiej-Salameh, bez której kontaktów i zdolności negocjacyjnych zaproszenie znamienitych Koleżanek i Kolegów zza oceanu byłoby niemożliwe, Jerzemu Kaczmarkowi, który podjął się przewodniczenia komitetowi organizacyjnemu, a także Andrzejowi Przestalskiemu oraz Piotrowi Luczysowi, dzięki pracy których konferencja nabrała finalnego kształtu.

\section{***}

Sądząc z wydarzeń minionego (2018) roku, można zasadnie twierdzić, że po stu latach Chłop polski... nie stracił potencjału inspirowania dyskusji naukowej. Nasuwają się jednak dwa mniej optymistyczne wnioski: o nieliniowym i zrywanym rozwoju refleksji będącej bezpośrednim nawiązaniem do Chłopa polskiego... i o pewnym osłabieniu zainteresowania dziełem na rodzimym gruncie, które jednak rekompensuje erupcja socjologii jakościowej „siłą rzeczy” (choć czasami mniej świadomie) odwołująca się do swoich własnych źródeł. Istotnym elementem tego, co pozostało, jest również świadomość znaczenia doświadczeń biograficznych podmiotu w kształtowaniu jego praktyk i wyczulenie na kwestie „mniejszościowości” w analizach socjologicznych współczesnych społeczeństw. Zamieszczone w niniejszym tomie artykuły stanowią, zdaniem redaktora, potwierdzenie wniosków i uwagi sformułowanej na początku wprowadzenia. Nie znaczy to jednak, że nie warto zagłębiać się w ich lekturę.

Przedstawione przez zaproszonych autorów interpretacje i nawiązania do Thomasa oraz Znanieckiego, jakkolwiek niewiele bądź nic nie mają wspólnego z formułą hagiografii, to ilustrują ciągle drzemiące w problematyce stulatka potencjały analityczne. Część z nich wynika po prostu z krytyki interpretacji zawartych w pracy, część zaś podejmuje wysiłek spojrzenia szerzej na Chłopa polskiego... nie tyle jako pewien wzór, co signum temporis - przedmiot studiów otwierający kontinuum poznawcze, pozwalając zestawiać teraźniejszość i przeszłość. W pewnym sensie Chłop polski... jest tylko, albo aż, „kamieniem milowym” i zapewne w takiej roli najczęściej obsadzali go zaproszeni do tomu autorzy. 


\section{Zawartość tomu ${ }^{6}$}

Tom składa się z tekstów inspirowanych na różne sposoby pięcioksięgiem Thomasa i Znanieckiego. Co warto podkreślić, grupuje kilka tekstów mogących służyć za swoiste drogowskazy współczesnych interpretacji refleksji poświęconych Chłopu polskiemu... Uzupełnieniem wstępu redaktora jest artykuł Ryszarda Cichockiego i Klaudii Jankowskiej zatytułowany „Chłop polski w Europie i Ameryce" a problem relacji pomiędzy badaniami socjologicznymi a ich aplikacjami dla potrzeb rozwiqzywania problemów społecznych, stanowiący zapis wiedzy zagregowanej w większości w polskiej tradycji badań inspirowanych twórczością Floriana Znanieckiego. Więcej nawet, jest także ilustracją spoglądania z polskiej perspektywy na proces społeczny (nazwany w tekście „paniką moralną” i „paniką społeczną”) prowadzący do pojawienia się zapotrzebowania na stosowane warianty empirycznej socjologii klinicznej. Jest to zatem pośrednio wskazanie na konotacje dzieła, które można znaleźć współcześnie w koncepcjach pomocy społecznej i pracy socjalnej, oraz na dualny charakter konstruowania opinii publicznej, z jednej strony będącej następstwem „oddolnego” przerażenia odmiennością (wskazanej paniki moralnej) i „odgórnego” niepokoju elit wywołanego zjawiskami podważającymi stabilność społeczną (co jak wiemy, również dzisiaj przykuwa naszą uwagę). W zakończeniu autorzy wyciągają wnioski dotyczące refleksyjności donatorów projektu badawczego finansującego badania „chłopa polskiego w Europie i Ameryce”, sugerując jednocześnie, że może to być wzór dla współczesnych. Opracowanie ma charakter w dużej mierze historyczny (autorzy określają je mianem „studium historycznego") i to stanowi jego wartość, bo pozwala zinterpretować sposób patrzenia poznańskiego środowiska na dorobek, który zakumulowały prace nawiązujące głównie do tradycji drugiego z współautorów Chłopa polskiego..., Floriana Znanieckiego, oraz wskazać, co dzisiaj dla ich przedstawicieli z niego wynika.

Część I tomu Praca z Chłopem polskim... otwiera tekst Kai Kaźmierskiej zatytułowany Pamiętnik imigranta jako przedmiot analizy w „Chłopie

${ }^{6}$ W przypadku trzech artykułów: Chada Alana Goldberga, Mary Erdmans oraz Josepha C. Hermanowicza publikujemy tłumaczenia artykułów przygotowanych pierwotnie do publikacji w języku angielskim dla potrzeb globalnych czytelników. Zrządzenie losu sprawiło, że tłumaczenie na język polski ukazało się wcześniej (w 2019 r.) niż pierwotnie planowana monograficzna publikacja zbiorowa. 
polskim w Europie i Ameryce”. Refleksja w stulecie wydania, poddający ocenie zgromadzony materiał z punktu widzenia współczesnych analiz autobiograficznych oraz unikatowej Noty metodologicznej, otwierającej (pytanie, na ile konsekwentnie w stosunku do analiz zawartych w pracy) pole refleksji socjologii humanistycznej. Jak wskazuje sama autorka: „Celem tekstu jest również ukazanie napięcia między pionierskim wkładem autorów w badania społeczne oraz zawartymi w Nocie metodologicznej deklaracjami a ich realizacją w odniesieniu do materiału empirycznego”. Tekst zmierza do wskazania słabości pięcioksięgu z punktu widzenia perspektywy współczesnych analiz biograficznych, a ponadto do wyekstrahowania z dłuższej tradycji socjologii humanistycznej tych elementów, które Chłop polski... uruchamia. Używając nieco prostszych słów, do uchwycenia tych rzeczy, które z perspektywy współczesnych analiz biograficznych „się bronią”, oraz tych, które wypada złożyć na karb genetyczności pracy i kosztów, jakie ponoszą pionierzy w swoim dziele eksplorowania nowych poznawczo obszarów. Ważne wydaje się to, że opracowanie Kaźmierskiej dokonuje swoistego historycznego skrótu, prowadzącego od przywołanego już „kamienia milowego”, dalej, w głąb przestrzeni badawczej socjologów. Jakkolwiek zadanie to jest złożone i raczej wykracza poza ramy artykułu, to jednak daje wyobrażenie bądź szkicuje ślad przebytej drogi. Ważne wydaje się pojawiające się systematycznie, także w wielu innych tekstach, nawiązanie do krytycznej wobec pracy Thomasa i Znanieckiego książki Herberta Blumera z końca lat trzydziestych XX w. (a zatem wydanej blisko dwadzieścia lat po Chłopie polskim... $)^{7}$, pracy, która w kontekście oceny recepcji tytułowego dzieła jest kluczowa.

Drugi z artykułów, Emocje w autobiografii Władka. Metoda autobiograficzna Thomasa i Znanieckiego na tle przykładu współczesnej analizy Fritza Schützego autorstwa Marka Nowaka i Piotra Luczysa, nawiązuje do tekstu otwierającego tom, przechodzi jednak do bardziej szczegółowych kwestii obecnych w Chłopie polskim... i stawia pytania o obecność emocji we wnioskowaniu Thomasa i Znanieckiego w relacji do współczesnych analiz Fritza Schützego i Kai Kaźmierskiej, w pewnym sensie podejmuje więc podobny problem, koncentrując się jednak bardziej na określonym aspekcie analizy (emocjach) niż na perspektywie metodologicznej czy też konkretnym wątku teoretycznym.

${ }^{7}$ Critiques of Research in the Social Sciences: I. An Appraisal of Thomas and Znaniecki's The Polish Peasant in Europe and America. New York: Social Science Research Council (1939). 
Konsekwencją przesunięcia przedmiotu refleksji badaczy - autorów opracowania jest z jednej strony próba teoretyzowania na temat emocji w tradycji socjologicznej, z drugiej zaś wskazanie na ewolucję samego fenomenu (emocji) w naukowej refleksji z początku XX w. Wnioski z analizy idą w trzech kierunkach. Po pierwsze, autorzy dostrzegają związek pomiędzy sposobem ujmowania emocji a tradycją socjologii, jaka była rozwijana na początku XX w., stąd również ich przekonanie, że mogą mieć w jej rozwoju pewien udział, po drugie, odpowiadają na pytanie o sens emocji w interpretacji Thomasa i Znanieckiego oraz we współczesnym, daleko bardziej wyrafinowanym ujęciu Schützego, a także, po trzecie, doszukują się związków pomiędzy strategią analityczną Schützego a funkcją przypisów w autobiografii Władka. To ostatnie jest próbą potraktowania znajdujących się na dole stron not jako protostrukturyzacji i skomasowania w jednym miejscu różnych etapów analizy autobiograficznej.

Od razu możemy zauważyć, że ani w jednym, ani w drugim przypadku emocje nie odgrywały per se znaczącej analitycznie roli, co można potraktować jako jeden z uogólniających wniosków artykułu dotyczących bezpośrednio kwestii wykorzystywania emocji w klasycznym tekście i w wybranej koncepcji analizy autobiograficznej. Wniosek ten jest, rzecz jasna, zakresowo wąsko sformułowany i jest wynikiem konkretnych studiów, a tym samym nie nadaje się do uogólniania na cały obszar badań autobiograficznych.

Kolejny artykuł Piotra Luczysa, socjologa zajmującego się historią socjologii polskiej i światowej, dotyczy zagadnienia recepcji pięcioksięgu Thomasa i Znanieckiego, a dokładnie, słowami samego autora: „uproszczeń i uogólnień czynionych na przestrzeni ostatnich stu lat przez czytelników pracy...”. Luczys dokonuje oceny dużego już zestawu prac będących bezpośrednim nawiązaniem do Chłopa polskiego..., koncentrując się na najmniej znanym (sadząc po recepcji) tomie piątym. Tekst zatytułowany Niechciane dziedzictwo. Piaty tom „Chłopa polskiego w Europie i Ameryce” a Chicago poczq̨tku $X X$ wieku w gruncie rzeczy powinien otwierać niniejszy tom ze względu na swój historyzujący charakter. Zawiera jednak wiele dość kontrowersyjnych tez, które powinny uruchomić dyskusję, choć niekoniecznie zdominować obraz numeru rocznicowego. Co warto podkreślić, oddając czytelnikowi prawo do własnych ocen, autor kolejnemu pokoleniu czytelników Thomasa i Znanieckiego sugeruje odwrócenie kolejności czytania dzieła. Według słów Luczysa: „Z konieczności, przy zastosowanym odwróceniu, ważniejsze staną się dociekania autorów poświęcone wyrywkowym elementom życia społeczności migrantów (zilustrowane wielokrotnie wspominanymi «materiałami osobistymi») niż peregrynacje teoretyczne”. 
Wartością pracy nie jest zatem to, co zwyczajowo uznajemy za główny element wkładu obydwu autorów, ale praktyka badawcza, której zapis obserwujemy, stanowiąca jej zastosowanie, ze wszystkimi ograniczeniami i pewnym poziomem niekonsekwencji autorów. Warto skądinąd zwrócić uwagę na wiele wątków historycznych, obejmujących np. zagadnienia przestępczości „polskich chłopów” w Ameryce, interpretowanych przez Znanieckiego i Thomasa na tle materiałów dających wyobrażenie życia społecznego ówczesnego Chicago. Autor opracowania dodaje do tego analizę ówczesnych artykułów prasowych, nawiązuje do kronik parafialnych i policyjnych, protokołów zeznań, przesłuchań etc., czyniąc obraz sprzed lat żywym i sugestywnym.

Kolejne dwa teksty tomu, zgrupowane w części II Zastosowania teorii i metody, w mniejszym stopniu stanowią metanarracje poświęcone Chłopu polskiemu..., w większym zaś propozycje rozwinięcia koncepcji obydwu autorów, bądź też próbują kontynuować zawarte tam wątki. Są to opracowania: Mary Patrice Erdmans „ Ja, jako psycholog, mówię ci...”: ontologiczna narracja uchodźcy opozycyjnego z epoki „Solidarności” - odwołujące się do zastosowania metody analizy autobiograficznej Thomasa i Znanieckiego, oraz Chada Alana Goldberga „Chłop polski w Europie i Ameryce” jako studium inkorporacji grup społecznych i budowania wspólnoty narodowejpodejmujące zagadnienia teoretyczne.

Pierwszy ze wskazanych tekstów składa się z dwóch wyraźnie oddzielonych części. Pierwsza podejmuje wysiłek rekonstrukcji głównych założeń dotyczących analizy autobiograficznej Thomasa i Znanieckiego, odwołując się nie tyle do współczesnych koncepcji, ile wprost do Chłopa polskiego..., co stanowi zapewne i zaletę tego tekstu, i pewną wadę, o czym przekonujemy się, śledząc recepcję książki Thomasa i Znanieckiego. Jak utrzymuje autorka: „Jednym z powodów, dla których biografie i inne dokumenty osobiste są niezbędne, jest fakt, że plasują one opowieści pojedynczych osób subiektywny obraz życia podmiotów społecznych - w samym centrum, pozwalając tym samym ludziom na nadanie znaczenia własnemu życiu, na opowiedzenie własnych historii”.

Ten element specyfiki materiału autobiograficznego w ujęciu Thomasa i Znanieckiego stał się podstawą szerszego projektu badawczego, którego składnikiem jest rekonstruowana i analizowana opowieść, bazująca na, według słów autorki: „losach uchodźców należących do pokolenia «Solidarności»; mowa tu o ludziach, którzy zostali zmuszeni do emigracji po wprowadzeniu w Polsce stanu wojennego, później zaś wrócili do kraju po upadku komunizmu". 
Przedmiotem analizy jest wywiad autobiograficzny z psychologiem związku zawodowego „Solidarność”: Wiktorem, uchodźcą z Polski. Paradoksalnie pobrzmiewa to, że podobnie jak w przypadku Władka, mamy do czynienia z nie do końca typowym przykładem biografii uchodźcy „solidarnościowego". Co ciekawe, aspektem czyniącym szczególnie interesującą tę autobiografię jest „kontrpolityczny” charakter jego postawy, co ilustruje w jego narracji skoncentrowanie na kwestiach zawodowych. Kontestuje on nie tyle system, choćby ze względu na jego autorytaryzm czy stosowanie przemocy, ile ekonomiczną irracjonalność „realnego socjalizmu”, a na tym tle przedstawia swoje własne wybory i ich dramatyczne konsekwencje. Specyfika postawy Wiktora jest interesująco opisana genetycznie w kontekście jego autobiografii, w której udziela m.in. bezpośrednich odpowiedzi na pytania, skąd się wywodzi jego postawa oraz w jakim stopniu jest to wyraz kulturowej specyfiki w rozumieniu, jakie temu pojęciu nadali Thomas i Znaniecki w Chłopie polskim... Jest to więc przykład argumentacji, w której kwestie samorealizacji i kariery zawodowej zdecydowały o wyjeździe (podobnie jak u Władka), w opozycji do wszelkich innych argumentów typowych, jak można przypuszczać, dla statusu kontestatora-opozycjonisty.

Drugi z wzmiankowanych tekstów istotnie się różni, jeśli chodzi o konceptualizację problematyki. Punktem wyjścia tekstu Chada Alana Goldberga jest nawiązanie do paradygmatu dezorganizacji społecznej, kojarzonego ze szkołą chicagowską. Problematyka ta, w oryginalnym ujęciu, związana była z kwestiami grup migranckich. Migracja sama zaś pojmowana była jako czynnik dezintegracji społecznej. Jakkolwiek zjawisko dezintegracji z czasem uruchamiało procesy reintegracji w nowy sposób, to sama dynamika rozpadu więzi i nawiązywania nowych była silnie związana z właściwościami kultury grupy migrującej i to na tym aspekcie koncepcji Thomasa i Znanieckiego Goldberg oparł swoją analizę. Przedmiotem jego zainteresowania były współczesne dla studium Thomasa i Znanieckiego badania dotyczące różnych zbiorowości etnicznych, w tym Żydów i Irlandczyków, oraz kontekst relacji pomiędzy grupami, których status społeczny w kraju pochodzenia i w kraju emigracji ulegał zmianie. Autor nie unika kontrowersji, co skądinąd czyni z jego tekstu niezwykle ciekawy kontrapunkt typowych analiz prowadzonych na podstawie Chłopa polskiego..., z punktu widzenia polskiej diaspory i w odniesieniu do jej relacji z dominującym społeczeństwem amerykańskim.

Zapraszamy do korzystania z przedstawionych treści. Proponujemy traktować prezentowany tom nie tyle jako domknięcie określonego etapu życia dzieła Thomasa i Znanieckiego (w świetle jego jubileuszu), ile jako 
kontynuację sztafety akademickich pokoleń, z których każde, od z górą stu lat, zmaga się z podobnymi zagadnieniami, w nieco inny sposób odpowiadając na pytania mające walor uniwersalnych pytań dyscypliny. Na tle tych opowieści dobrze widać kierunek kumulacji wiedzy socjologicznej, a w praktyce jej intensywny rozwój i specjalizację. No i jeszcze jeden aspekt, który rzadziej jest eksponowany: można dostrzec skłonność do zapominania. To ostatnie, zdaniem redaktora, nie przynosi nam chluby, choć zapewne czyni łatwiejszym poruszanie się w przestrzeni dyscypliny, która „zakumulowała” już co najmniej cztery pokolenia badaczy i stała się kanonem akademickiego kształcenia. 
